\title{
Looking Out and Looking In : Exploring a Case of Faculty Perceptions During E-Learning Staff Development
}

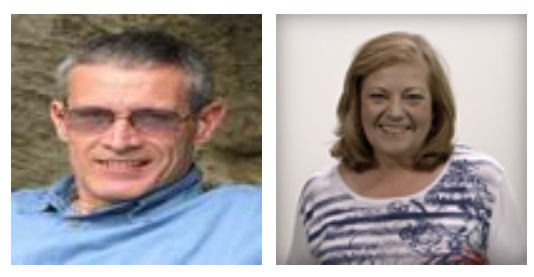

Hendrik Daniël Esterhuizen, Seugnet Blignaut, and Suria Ellis (not shown) North-West University, South Africa

\section{Abstract}

This explorative study captured the perceptions of faculty members new to technology enhanced learning and the longitudinal observations of the e-learning manager during dedicated professional development in order to compile a socially transformative emergent learning technology integration framework for open and distance learning at the School of Continuing Teacher Education at North-West University, South Africa. A pragmatic approach guided the bounded case study. The study followed a fully mixed sequential equal status design of mixing sequential qualitative and quantitative findings. Data collection strategies concern a custom-made questionnaire, interviews with faculty members, and longitudinal observations by the e-learning manager. The first phase uncovered 34 qualitative codes. After quantitating of the data, a t-test indicated significant differences for 17 variables between faculty perceptions and observations of the e-learning manager. Ward's method of Euclidean distances grouped the variables into five clusters according to the researchers' paradigm of looking in and looking out from the development context. The clusters formed the basis of a model for faculty development towards socially transformative learning technology integration for open distance learning. The five aspects of the model comprise (i) the environment in which faculty members should gain support from the institution; (ii) the environment in which faculty have to address the realities of adopting TEL; (iii) human factors relating to the adoption of TEL; (iv) concerns and reservations about the use of TEL; and (v) continuing professional development needs, expectations, and motivators. The sustainable integration of ICT into higher education institutions remains a major challenge for the adoption of TEL. 
Keywords: Technology enhanced learning (TEL); teacher training; professional development; mixed methods research; interactive white boards; developing context; technophobia

\section{Introduction}

Spotts (1999) identifies five significant e-learning variables, the learner, faculty, technology, environment, and perceived value, in an effort to obtain information beneficial to faculty development of technology enhanced learning (TEL). However, implementing

e-Learning could be a highly disruptive technology for education-if we allow it to be...if there is to be innovation and change in university teaching -as the new technology requires, as the knowledge economy requires, and as students demand-someone has to take responsibility for it. Who should that be, other than the university academic community? (Laurillard, 2006, p. 5)

These statements indicate that the final successes of implementing TEL at higher education institutions (HEIs) are to a great extent in the hands of faculty members. However, in many cases, faculty members require intensive pedagogical, knowledge, and skills training to make a real difference in the deposition of their learners.

Utilizing the potential of IT in educational practice often implies that the role of the teacher has to change. Faculty not only has to learn IT basic knowledge and skills, but more importantly, has to learn appropriate pedagogical skills to be able to integrate IT in a sound way into educational practice. (Voogt \& Knezek, 2008, p. xxxiii)

More than simple knowledge of technology is required to produce good teaching. Exemplary teaching combines skillful use of technology, embedding key elements into course design (Wilson, 2003). This paper explores the lived experiences of faculty in a developing context while they for the first time engage with TEL.

\section{Context of the Study}

This paper forms part of a larger investigation to establish a socially transformative emergent learning technology integration framework for open and distance learning (ODL) at the School of Continuing Teacher Education (SCTE) at North-West University (NWU) (Esterhuizen \& Blignaut, 2011; Esterhuizen, Blignaut, Ellis, \& Els, 2012). It explores with the aim to understand the lived experiences of faculty at a developing 
ODL unit and subsequently forms part of the cyclic process of data gathering in which emerging themes initiate further data gathering cycles.

The SCTE employs few learning technologies to teach and support students within an ODL model of course delivery. These include compact disc read only memory (CDROM), short message service (SMS), and interactive white boards (IWBs). To enable students' participation in the information society, teacher training should include use of information communication technology (ICT). Faculty require competence in ICT use to enable their learners to develop their full potential. ICT can be a vehicle to personalise learning, provide access to information, provide flexibility regarding time, place, and pace of learning, and enable collaboration and continued study even while working full time (Ally, 2009; UNESCO, 2002).

The South African Government's White Paper on e-Education (Department of Education, 2004) demands a definite outcome of ICT mastery as a matter of urgency in teacher training and teachers should have access to in-service training on how to integrate ICTs into teaching and learning. The e-Education White Paper acknowledges the backlog in its e-learning expectations and calls for development actions in this regard:

Many teachers have grown up in an environment that had less electronic technology available, and thus find the adaptation to working with ICT more difficult than their learners. A programme that urgently addresses the competencies of teachers to use ICT for their personal work, in their classrooms, should be developed. This will require extensive staff development and support. Thus, ICT will be central to the pre-service training of recruits and the on-going professional development of practising teachers. (Department of Education, 2004, p. 22)

The perceptions of faculty members as the enablers of adoption are at the heart of this exploration. The SCTE acknowledges the requirement for the advancement of elearning in the development of a learning technology integration framework. It is necessary for teachers in training at the SCTE to adopt e-learning using ICT. Teachers' adoption of technology is influenced by both the quantity and quality of experiences with technology (Moolman \& Blignaut, 2008) included in their teacher education programs (Agyei \&Voogt, 2011).

The SCTE is in the process of evolving from paper-based distance education delivery to adopting TEL as part of ODL. In order to advance from physically travelling to lecture at one tuition center at a time to reaching remote facilitators and students simultaneously at 39 tuition centers across Southern Africa, the SCTE introduced synchronous computer mediated conferencing using interactive whiteboards (IWBs) at tuition centers. Faculty training in the use of IWBs necessitates developing faculty 
competencies both in the area of technology use and in managing synchronous computer-mediated communication learning.

\section{Literature Review}

Distance education endeavours to expand access to education through the mass production of teaching and course materials, often largely based upon one-way transmission of information with little chance for sustained interaction. The face-toface lecture is still viewed as the most efficient and dominant medium of instruction in higher education. However, "communications technology that supports sustained interaction is having a significant impact in higher education-both on-campus and at a distance" (Anderson \& Garrison, 1998, p. 97). Wilson (2003) indicates that some of the reasons for using technology in teaching and learning are that it could improve student learning, benefit students in their research and communication, foster independent learning, provide access to worldwide resources, and improve career choices. Schneckenberg, Ehlers, and Adelsberger (2011) indicate that, in many cases, faculty concerns for their students motivate them to walk the extra mile of implementing TEL for the benefit of their students - a concern often more powerful than personal financial considerations.

Faculty unaccustomed to using technology in their teaching and learning-because they did not grow up with the technology, or have not personally tried out the technologycannot draw from their lived experiences, or from their recent introduction to the technology. Faculty have to first-hand experience the affordances of learning technologies to effectively use them during teaching and learning. Faculty professional development is essential to introduce them to new technologies, ensure smooth adoption, and provide experience with the technology. However, successful faculty development interventions (i.e., ones that encourage faculty to adopt new technologies) should not only focus on the mechanical and technical aspects of TEL, but also place emphasis on appropriate pedagogy, address individual teaching beliefs, provide real life interaction as their online students would, and contextualize the professional development in terms of the local needs of the faculty. It is important to focus first on pedagogy and then on technology when training faculty, as well as when faculty adopt technology for student learning (Simpson, 2002).

As front-line enablers of adoption, faculty should experience the affordances of elearning personally. This will enable them to convincingly adopt technology for teaching and learning of teacher-students at SCTE, and to adopt the concept of personal learning environments (PLEs)-learning environments like learning management systems (LMSs) (Attwell, 2007). To promote development of PLEs for faculty and student benefit, prevailing faculty perceptions on gainful e-learning should be explored. Faculty pedagogical practices should align with the needs of students. Faculties of inservice settings have to adapt their pedagogical approaches to learn how TEL could be 
used to facilitate pedagogical approaches across different contexts. Christensen and Knezek (2008) have shown that faculty's attitudes towards ICT, their ICT competencies, and their access to ICT tools affect their use of technology. TEL competency is not limited to basic TEL knowledge and skills, but especially faculty's ability to combine content knowledge with TEL pedagogy.

The emerging pedagogical consensus is that constructivism is the most preferred and effective way of using online learning technology in order to support students during collaboration, authentic tasks, reflection, and dialogue (Mayes, 2001). Faculty that employ traditional teaching and learning styles may view learning technology as less appropriate and feel less positive about using TEL than those who believe in studentcentered approaches. In an effort to supplement or replace live contact teaching and learning, technology-mediated distance learning frequently replicates the activities of face-to-face classrooms. Interactive technologies, like IWBs, are consequently employed to present one-way presentations to students in remote locations, thus furthering instructivist pedagogy. The most valuable activity in a classroom of any kind is the opportunity for students to work and learn together (J onassen, Davidson, Collins, Campbell, \& Haag, 1995).

Anderson and Garrison (1998) are of the opinion that education depends on acts of communication, but communication should be reciprocal, consensual, and collaborative to fully qualify as being educational. Collaboration implies shared control-not only one-way transmission of information without considering the process of constructing meaningful and worthwhile knowledge. Educational communication should explain why a concept makes sense or does not, and not simply state that it is right or wrong. It should be explanatory and not just confirmatory. Adopting a learner-centered pedagogy during the use of TEL often represents a radical paradigm shift when faculty members are accustomed to instructivist teaching styles. Poorly managed adoption of constructivist online learning may result in faculty and students feeling threatened. Transformation to TEL adoption should therefore be based on professional development with approaches to provide faculty with experience of using technology first hand (Ehlers \& Schneckenberg, 2008). Anderson and Van Weert (2002) identify four broad and continuous approaches through which educational systems proceed in their adoption and use of ICT: emerging, applying, infusing, and transforming. In the process of transforming from traditional distance education, adopting constructivist pedagogy to cultivate e-learning methods involves interaction, collaboration, and nurturing the perceptions of faculty on the value of electronic learning technologies and their usefulness for collaboration essential for developing appropriate strategies and training approaches: "Academic development is most likely to succeed when the teacher's own beliefs about teaching and learning provide the starting point" (Errington, 2001).

Implementing TEL is complex, often ill-structured, and requires faculty to adopt alternative ways of grasping and acting on the complexity. At the heart of good TEL lie three core components, content, pedagogy, and technology, as well as the relationships 
amongst and between them. These three core components form the core of the technology, pedagogy, and content knowledge (TPACK) framework (Koehler \& Mishra, 2009). Interacting with these components and the relationships between them, across a variety of diverse contexts, accounts for wide variations in the extent and quality of TEL integration (Hinostroza, Labbé, López, \& ost, 2008). Although TPACK is not enough for the integration of TEL, it determines faculty outlook towards educational change (Law, 2008). A learning-by-design approach requires faculty to navigate the complex interface between tools, authentic learning tasks, students, and learning contexts. Faculty can thereby explore TEL and develop ways of thinking about technology, design learning, and develop TPACK (Koehler \& Mishra, 2005). Traditional methods of TEL training, mainly workshops and face-to-face courses, are ill-suited to produce the deep understanding required for faculty to become knowledgeable users of TEL.

It is not only faculty who should change their attitude towards the integration of TEL in their courses. Institutional organizational structures and contexts should allow faculty to experiment and adopt new pedagogical approaches. Leadership at HEIs should make provision in their strategic planning to integrate TEL across their institutions, providing facilities for faculty to develop a vision on why and how to integrate TEL into teaching and learning, and providing support across all administrative, technical, and pedagogical areas (Elton, 1999; Riel \& Becker, 2008). Leadership at HEIs should therefore

...exert some influence over the way in which e-learning is used in universities, and direct its power overtly towards the needs of learners. Change in universities is an aspect of their organisation, and again, the opportunities of the new learning technologies, including all their capabilities for information processing, communications, mass participation, design, and creativity, support the kind of system structure that would enable change to be organic and progressiveadaptive rather than mechanistic. (Laurillard, 2006, p. 12)

Lastly, the faculty professional development trainer should assist in identifying and defining training problems, obtaining commitment in practice from faculty, simulating positive experiences of ODL students in TEL, designing pedagogically sound course units, identifying learning problem scenarios with faculty members; designing pedagogical objectives that encourage students to make autonomous decisions while engaging with complex context, creating real-world learning tasks for students, and encouraging faculty to take responsibility of their own professional development. In short the role of the professional development trainer is to create scenarios in the learning environment that reflect the complexity and uncertainty of decision-making in real TEL contexts (Ehlers \& Schneckenberg, 2008). 


\section{Research Design and Methodology}

\section{Study Participants}

The study participants related to two categories: the 21 academic faculty members from an ODL unit, the SCTE at NWU, and the e-learning manager. During their course design activities, the faculty members create course content, support students, and assess learning tasks and examination papers of under qualified and unqualified teacher-students across South Africa and Namibia. The e-learning manager over a period of more than two years interacted with the faculty members daily, providing training in the use of interactive electronic whiteboards for synchronous computer mediated communication, assisting in general computer use and literacy, sourcing of material for remote lecturing, and facilitating the recording of educational DVDs. His TEL involvement related to liaising with institutional committees on TEL at NWU, leading a NWU research project on TEL for ODL, strategic planning of TEL at the SCTE; developing a people-centered socially transformative learning technology integration framework for TEL for ODL, developing and implementing TEL infrastructure, and training of faculty on the design and implementation of TEL for ODL. This paper evolved from the culmination of the above roles.

\section{Methods}

This study stemmed from the pragmatic perspective that

is characterised by a concern for providing explanations of the status quo, social order, consensus, social integration, solidarity, needs satisfaction and actuality. It is a perspective concerned to understand society in a way which generates knowledge which can be put to use. It is often problem-orientated in approach, concerned to provide practical solutions to practical problems. (Burrell \& Morgan, 1979, p. 26)

A pragmatic approach guided "an intensive [bounded case] study of a single unit with an aim to generalize across a larger set of units" (Berring, 2004, p. 341) in order to provide fitting resolutions on how to guide faculty towards TEL competency. The research plan encompassed a fully mixed sequential equal status design of mixing of sequential qualitative and quantitative findings during the analysis of the data (Leech \& Onwuegbuzie, 2009) (Figure 2). 


\section{Instruments}

The main three strategies collected data from the two sets of research participants:

(i) a custom-made questionnaire that collected (a) quantitative data from two questions (one binary and one Likert scale data), measuring faculty commitment to the adoption of TEL; (b) qualitative data from two open-ended questions on elaboration of the commitment; (c) quantitative data from an open-ended question, requesting faculty members to list learning technologies they have considered before; and (d) qualitative data from five open-ended questions on the perceptions of faculty on the use of learning technology in ODL (Table 1);

(ii) individual interviews with four purposefully selected faculty members selected according to the criterion that they, at that point of the research, have completed making an interactive DVD as part of their electronic study material for their respective courses; and

(iii) a concatenation of the reflective journals of the e-learning manager at the SCTE. The e-learning manager recorded all academic staff meetings, discussions, academic training, as well as technology task team meetings on learning technology integration and the development of e-learning. Such meetings included central university management and management of various service departments. The observations document included viewpoints from all the role players in relation to faculty experience and context. This summative document became the comparative voice to those of the faculty members during the qualitative analysis (Figure 2). 


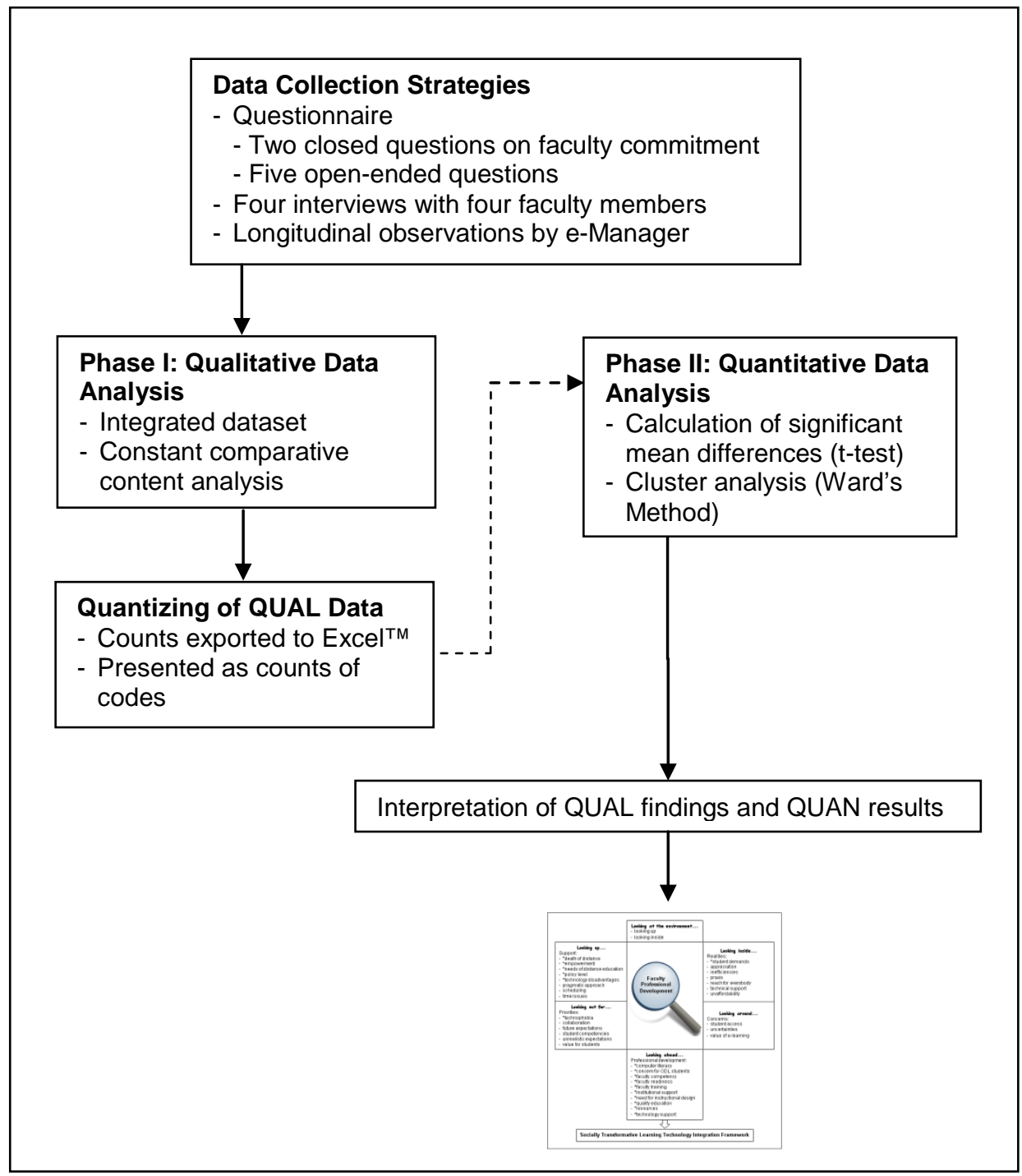

Figure 1. Pragmatic research design exploring faculty needs for technology enhanced learning.

\section{Qualitative Analysis}

The textual documents relating to the four interviews, captured as direct transcripts, the responses to five open-ended questions in the questionnaire, and the reflective document were assigned to Atlas.ti ${ }^{\mathrm{TM}}$, a computer assisted qualitative data analysis system, as an integrated dataset (Figure 2). The analysis followed Boeije's (2002) constant comparative process of qualitative content analysis where codes were allocated to sections of data, and subsequently each piece of data was compared with every other piece of relevant data. The content analysis resulted in 34 codes (Table 1) with a total of 457 quotations linked to the codes. After the qualitative analysis the data were 
quantitised (Saldãna, 2009) and captured in Excel ${ }^{\mathrm{TM}}$ for further quantitative analysis with Statistica $^{\mathrm{TM}}$ data analysis software system (StatSoft Inc., 2011) (Figure 2).

\section{Quantitative Analysis}

The questionnaire prompted the faculty members on their intention to implement elearning at the SCTE and whether they considered it essential to increase the use of $\mathrm{e}$ learning technologies in open distance learning initiatives. A further question requested respondents to compile a list of learning technologies they considered important. The first question elicited a five-point Likert scale response where $5=$ I definitely commit; 4 =I commit; 3 =I am neutral; 2 =I do not commit; 1 = I definitely do not commit. The second required a binary response where Yes $=1$ and No $=0$. The responses to the open-ended question, requesting the respondents to list learning technologies they considered important, were captured and counted (Table I).

The quantitised (Saldãna, 2009) qualitative data were subjected to two statistical procedures: (i) testing for significant differences between the means of the two groups (faculty and e-learning manager) and (ii) cluster analysis of the codes in order to compile a model for faculty development relating to the use of technology enhanced learning in ODL. Cluster membership was assessed by calculating the total sum of squared deviations from the mean of a cluster. The criterion for fusion is that it should produce the smallest possible increase in the error sum of squares (Burns \& Burns, 2008). The cluster analysis was performed according to Ward's minimum variance method. Ward's method provides a special case for measuring the objective function of Euclidean distances that ensures minimum distance between elements and maximum distance between clusters (Cohen, Manion, \& Morrison, 2011). This method is most appropriate for quantitative, but not binary variables. It is distinct from other methods because it uses an analysis of variance approach to evaluate efficient distances between clusters (McMillan \& Schumacher, 2001).

\section{Results and Discussion}

Table 1 lists faculty members' responses to their commitment of using e-learning during their teaching and learning on a five-point Likert scale, as well as their opinion on the value of e-learning. The faculty member who selected the neutral response in terms of his commitment to e-learning explained that he was not involved in lecturing at that point of time. He also selected No for the same reason in the second question. 
Table 1

Faculty Committing to the Use of TEL

\begin{tabular}{|c|c|}
\hline Question and scale & Responses \\
\hline \multicolumn{2}{|c|}{ Question 1: I am committed to implementing e-learning } \\
\hline I definitely commit & 19 \\
\hline I commit & 1 \\
\hline I am neutral & 1 \\
\hline I do not commit & 0 \\
\hline I definitely do not commit & 0 \\
\hline \multicolumn{2}{|c|}{$\begin{array}{l}\text { Question 2: I consider it essential to increase the use of e-learning technologies in ODI } \\
\text { initiatives }\end{array}$} \\
\hline Yes & 18 \\
\hline No & 1 \\
\hline \multicolumn{2}{|c|}{ Question 3: I consider the following as examples of e-learning technologies } \\
\hline Interactive whiteboard & 17 \\
\hline SMS: mobile phones & 12 \\
\hline Internet: e-mail & 10 \\
\hline LMS: Moodle / e-Fundi & 9 \\
\hline iPad / iPod & 5 \\
\hline DVD / MMD & 2 \\
\hline Mobisites & 2 \\
\hline $\begin{array}{l}\text { Others: Computer gadgets; e-readers, social } \\
\text { networks, iPhone, m-Learning, radio, reading } \\
\text { literacy labs, screencasts, Skype, Web2.0 }\end{array}$ & 1 each \\
\hline
\end{tabular}

The discussion of the results takes place from a firm faculty commitment to participation in the adoption of e-learning, and a conviction that it is essential to increase the use of e-learning technologies in ODL initiatives. Yet, faculty have limited perspectives on the scope of learning technologies, as well as their affordances for ODL. During interviews conducted at the start of the active development process, faculty informally named only seven examples of learning technologies, maintaining that they had not been exposed to others. After the introduction of IWBs, while some could only refer to different technologies, others could discuss their use and affordances (Table 1).

A t-test calculated significant differences between the means of the perceptions from faculty (looking out) and the e-learning manager's observations (looking in). Table 2 indicates that significant differences occurred in 17 of the 34 variables. 
Table 2

Calculation of Significant Differences between Faculty Perceptions (Looking Out) and Observations of e-Learning Manager (Looking In)

\begin{tabular}{|c|c|c|c|c|c|}
\hline Variable & $\begin{array}{c}\text { Mean } \\
\text { outa }^{\mathrm{a}}\end{array}$ & $\begin{array}{l}\text { Mean } \\
\text { in }^{\mathrm{b}}\end{array}$ & t-value & $\mathrm{p}$ & Std dev outa \\
\hline * Computer literacy & 1.67 & 18 & -8.28 & 0.000 & 1.87 \\
\hline * Concern for students & 3.11 & 15 & -3.84 & 0.005 & 2.93 \\
\hline * Death of distance & 0.89 & 7 & -7.42 & 0.000 & 0.78 \\
\hline * Empowerment & 0.67 & 5 & -2.91 & 0.020 & 1.41 \\
\hline * Faculty competency & 4.67 & 17 & -2.38 & 0.045 & 4.92 \\
\hline * Faculty readiness & 2.22 & 10 & -2.31 & 0.050 & 3.19 \\
\hline * Faculty training & 6.11 & 20 & -2.55 & 0.034 & 5.16 \\
\hline * Institutional support & 2.00 & 15 & -5.52 & 0.001 & 2.24 \\
\hline $\begin{array}{l}* \text { Need for instructional } \\
\text { design }\end{array}$ & 3.11 & 18 & -3.94 & 0.004 & 3.59 \\
\hline $\begin{array}{l}\text { * Needs of distance } \\
\text { education }\end{array}$ & 0.67 & 6 & -4.53 & 0.002 & 1.12 \\
\hline * Policy level & 0.11 & 6 & -16.76 & 0.000 & 0.33 \\
\hline * Quality education & 0.44 & 16 & -14.56 & 0.000 & 1.01 \\
\hline * Resources & 0.44 & 14 & -9.64 & 0.000 & 1.33 \\
\hline * Student demands & 0.56 & 2 & -2.60 & 0.032 & 0.53 \\
\hline * Technology disadvantages & 1.22 & 5 & -2.57 & 0.033 & 1.39 \\
\hline * Technology support & 1.22 & 14 & -8.69 & 0.000 & 1.39 \\
\hline * Technophobia & 1.89 & 10 & -2.36 & 0.046 & 3.26 \\
\hline Appreciation & 0.67 & 1 & -0.28 & 0.784 & 1.12 \\
\hline Collaboration & 2.11 & 7 & -2.05 & 0.074 & 2.26 \\
\hline Future expectations & 1.44 & 2 & -0.24 & 0.820 & 2.24 \\
\hline Inefficiencies & 0.67 & 2 & -0.96 & 0.367 & 1.32 \\
\hline Pragmatic approach & 2.22 & 5 & -1.61 & 0.147 & 1.64 \\
\hline Praxis & 1.44 & 0 & 1.55 & 0.159 & 0.88 \\
\hline Reach for everyone & 0.33 & 0 & 0.63 & 0.545 & 0.50 \\
\hline Scheduling & 2.00 & 2 & 0.00 & 1.000 & 2.00 \\
\hline Student access & 4.33 & 0 & 1.20 & 0.265 & 3.43 \\
\hline Student competencies & 2.11 & 8 & -2.10 & 0.069 & 2.67 \\
\hline Technical support & 1.00 & 2 & -0.67 & 0.521 & 1.41 \\
\hline Time issues & 2.11 & 3 & -0.28 & 0.784 & 2.98 \\
\hline Unaffordability & 0.33 & 0 & 0.45 & 0.667 & 0.71 \\
\hline Uncertainties & 3.78 & 5 & -0.38 & 0.712 & 3.03 \\
\hline Unrealistic expectations & 2.78 & 9 & -187 & 0.098 & 3.15 \\
\hline Value for students & 1.22 & 4 & -1.33 & 0.221 & 1.99 \\
\hline Value of e-learning & 5.78 & 9 & -0.58 & 0.576 & 5.24 \\
\hline
\end{tabular}




\begin{tabular}{|ll|l|l|l|l|}
\hline Variable & $\begin{array}{c}\text { Mean } \\
\text { out }^{\mathrm{a}}\end{array}$ & $\begin{array}{c}\text { Mean } \\
\text { in }^{\mathrm{b}}\end{array}$ & t-value & $\mathrm{p}$ & Std dev out $^{\mathrm{a}}$ \\
\hline $\mathrm{a}$ & Faculty observations \\
\hline $\mathrm{b}$ & e-learning manager's longitudinal observations \\
\hline$*$ & Significant difference $\mathrm{p} \leq 0.05$ \\
\hline Df: & 8 \\
\hline Valid N Out $\mathrm{b}:$ & 9 \\
\hline Valid N In $\mathrm{a}:$ & 1 \\
\hline Std Dev In $\mathrm{a}:$ & 0
\end{tabular}

A cluster analysis according to Ward's method using Euclidean distances was used to cluster the 34 variables into five clusters (Figure 2). Figure 2 reflects the researchers' adoption of the metaphor of faculty members looking out from their perspective of acquiring TEL competencies for ODL, and the e-learning manager's perspective of looking into their development. The cluster analysis resulted in five cluster themes: (i) looking up, the environment in which faculty members are expected to adopt learning technology use from the perspective of support from above; (ii) looking inside, the environment in which faculty members are expected to adopt learning technology use from the perspective of inherent realities; (iii) looking out, human factors relating to the adoption of learning technologies; (iv) looking around, concerns and reservations about technology use; (v) looking ahead, continuing professional development needs, expectations, and motivators.

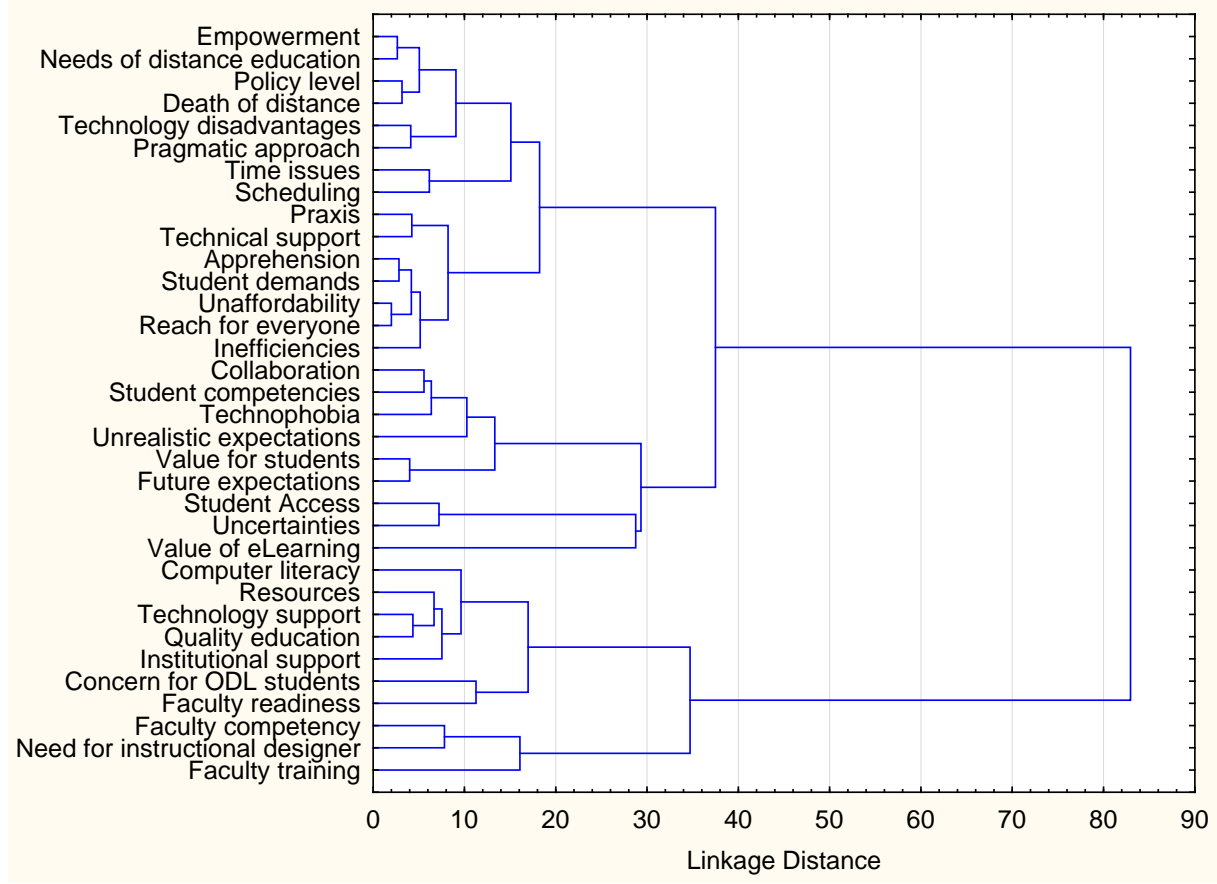

Figure 2. Clustering tree diagram for 34 variables according to Ward's method for Euclidean distances. 
Table 3 depicts the five cluster themes (Figure 2) as a discussion framework for implementing TEL at the SCTE. It lists the five cluster themes (looking up, looking inside, looking at, looking around, and looking ahead), as well as the variables that faculty and the elearning manager during the statistical analysis agreed upon and those that deferred.

Table 3

Cluster Themes with Agreement and Contrast Between Intensities

\begin{tabular}{|c|c|c|}
\hline Themes & Agreement & Contrast \\
\hline $\begin{array}{l}1 \quad \text { Looking up } \\
\text { The environment in } \\
\text { which faculty members } \\
\text { are expected to adopt } \\
\text { TEL use from the } \\
\text { perspective of support } \\
\text { from the institution }\end{array}$ & $\begin{array}{l}\text { - pragmatic approach } \\
\text { - scheduling } \\
\text { - time issues }\end{array}$ & $\begin{array}{l}\text { - *death of distance } \\
\text { - *empowerment } \\
\text { - *needs of distance } \\
\text { education } \\
\text { - *policy level } \\
\text { - *technology disadvantages }\end{array}$ \\
\hline $\begin{array}{l}2 \text { Looking inside } \\
\text { The environment in } \\
\text { which faculty members } \\
\text { are expected to adopt } \\
\text { TEL from the } \\
\text { perspective of local } \\
\text { realities }\end{array}$ & $\begin{array}{l}\text { - appreciation } \\
\text { - inefficiencies } \\
\text { - praxis } \\
\text { - reach for everybody } \\
\text { - technical support } \\
\text { - unaffordability }\end{array}$ & • *student demands \\
\hline $\begin{array}{l}3 \text { Looking at } \\
\text { Human factors relating } \\
\text { to the adoption of TEL }\end{array}$ & $\begin{array}{l}\text { - collaboration } \\
\text { - future expectations } \\
\text { - student competencies } \\
\text { - unrealistic expectations } \\
\text { - value for students }\end{array}$ & - *technophobia \\
\hline $\begin{array}{l}4 \quad \text { Looking around } \\
\text { Concerns and } \\
\text { reservations about the } \\
\text { use of TEL }\end{array}$ & $\begin{array}{l}\text { - student access } \\
\text { - uncertainties } \\
\text { - value of e-learning }\end{array}$ & \\
\hline $\begin{array}{l}5 \text { Looking ahead } \\
\text { Continuing professional } \\
\text { development needs } \\
\text { expectations and } \\
\text { motivators }\end{array}$ & & $\begin{array}{l}\text { - *computer literacy } \\
\text { - *concern for ODL students } \\
\text { - *faculty competency } \\
\text { - *faculty readiness } \\
\text { - *faculty training } \\
\text { - *institutional support } \\
\text { - *need for instructional } \\
\text { design } \\
\text { - *quality education } \\
\text { - *resources } \\
\text { - *technology support }\end{array}$ \\
\hline
\end{tabular}

* Significant difference $\mathrm{p} \leq 0.05$

Table 2 indicates that no significant differences occurred in two clusters between the perceptions of faculty members and the observations of the e-learning manager between (i) the variables in cluster 1, looking around, the concerns and reservations about 
technology use, student access, uncertainties, and value of e-learning and (ii) the variables in cluster 5, looking ahead, continuing professional development need and motivators, computer literacy training, concern for ODL students, faculty competency, faculty readiness, faculty training, institutional support, need for instructional design, quality education, resources, and technology support. Theme 1 shows the largest number of discrepancies between the perceptions of the faculty and the observations of the e-learning manager. While faculty focused on their daily work-related challenges, following a pragmatic approach, scheduling, and general time issues, the e-learning manager's attention related to more strategic issues: death of distance (the irradiation of the negative effects of distance education), empowerment of faculty and learners, needs of distance education, policy level issues, and disadvantages that the adoption of technology posed for the SCTE. Clusters 2 and 3 only relate differences with regard to one variable each, contrasting the observations of the e-learning manager and the perceptions of the faculty. Again, in both cases, the observations of the e-learning manager related to strategic issues, while the perceptions of faculty zoomed in on their daily practices.

From the looking-in perspective of the e-learning manager, variables such as the need for instructional design to be freely available to faculty, the improvement of faculty computer literacy and faculty competency in pedagogical application through learning technologies in quality education, concern for ODL students, institutional support, technology support, resources, faculty readiness, and technophobia all relate to themes to be addressed during faculty professional development for the adoption of TEL. From the perceptions of the faculty looking out, perspectives on staff development are dominated by a strong plea for comprehensive practice-based faculty training. Next, the value of e-learning is in high regard, followed by concerns over faculty competency, access of students to the Internet and to ICT technology, reservations about the possibilities of e-learning adoption, concern for ODL students' needs, and need for instructional design to effect e-learning development. Further instances revolve around unrealistic expectations (faculty's perception of performing functions which they are neither trained for nor have experience in), faculty readiness (committed to the mission of SCTE to use TEL), pragmatic approach, insufficient student competencies, collaboration, time issues, institutional support, scheduling, technophobia, and computer literacy. These relate to 17 of the 34 codes in order of intensity. These issues are graphically depicted in Figure 3 as a model for faculty development towards socially transformative learning technology integration for ODL. 


\begin{tabular}{|c|c|c|}
\hline & $\begin{array}{l}\text { Looking at the environment... } \\
\text { - looking up } \\
\text { - looking inside }\end{array}$ & \\
\hline $\begin{array}{l}\quad \text { Looking up... } \\
\text { Support: } \\
\text { - *death of distance } \\
\text { - *empowerment } \\
\text { - *needs of distance education } \\
\text { - *policy level } \\
\text { - *technology disadvantages } \\
\text { - pragmatic approach } \\
\text { - scheduling } \\
\text { - time issues }\end{array}$ & $\begin{array}{c}\text { Faculty } \\
\text { Professional } \\
\text { Development }\end{array}$ & $\begin{array}{l}\quad \text { Looking inside.. } \\
\text { Realities: } \\
\text { - *student demands } \\
\text { - appreciation } \\
\text { - inefficiencies } \\
\text { - praxis } \\
\text { - reach for everybody } \\
\text { - technical support } \\
\text { - unaffordability }\end{array}$ \\
\hline \multirow[t]{2}{*}{$\begin{array}{l}\text { Looking at... } \\
\text { Priorities: } \\
\text { - *technophobia } \\
\text { - collaboration } \\
\text { - future expectations } \\
\text { - student competencies } \\
\text { - unrealistic expectations } \\
\text { - value for students }\end{array}$} & & $\begin{array}{l}\quad \text { Looking around. } \\
\text { Concerns: } \\
\text { - student access } \\
\text { - uncertainties } \\
\text { - value of e-learning }\end{array}$ \\
\hline & $\begin{array}{l}\text { Looking ahead... } \\
\text { Professional development: } \\
\text { - *computer literacy } \\
\text { - *concern for ODL students } \\
\text { - *faculty competency } \\
\text { - *faculty readiness } \\
\text { - *faculty training } \\
\text { - *institutional support } \\
\text { - *need for instructional design } \\
\text { - *quality education } \\
\text { - *resources } \\
\text { - *technology support }\end{array}$ & \\
\hline \multicolumn{3}{|c|}{ Socially Transformative Learning Technology Integration Framework } \\
\hline
\end{tabular}

Figure 3. Model for faculty development towards socially transformative learning technology integration for open distance learning ( $*$ significant difference $\mathrm{p} \leq 0.05$ ).

\section{Conclusions and Recommendations}

This explorative analysis according to a multimode research methodology resulted in a model indicating (i) the environment in which faculty members adopt TEL from the perspective of support from the institution; (ii) the environment in which faculty members adopt TEL from the perspective of local realities; (iii) the human factors relating to the adoption of TEL; (iv) the concerns and reservations relating to the use of TEL; and (v) the continuous professional development needs, expectations, and motivators of faculty. This analysis indicated the agreement and disagreement of the development variables between the perceptions of the faculty and the observations of the e-learning manager. While the faculty mainly zoomed in on TPACK issues (Mishra \& Koehler, 2006), the e-learning manager zoomed out to strategic issues in order to 
gradually shift the teaching and learning approach from an instructivist towards a more constructivist approach (J onassen, et al., 1995).

The analysis indicated that faculty perceptions at the onset of a transition process from paper-based distance education to e-learning adoption reflected a need for comprehensive practice-based faculty training. This is motivated by the plight of the SCTE ODL teacher-students-practicing teachers on whom thousands of learners depend for an education. The five aspects of the model (Figure 3) drive the adoption of TEL at the SCTE. Faculty look up for support from management to look inside the institution to provide procedural support in terms of pragmatic approaches to focus on TEL adoption (Schneckenberg, et al., 2011). Faculty request measures to manage their workload and scheduling of pedagogical priorities, interventions to overcome technological unfamiliarity, and TPACK training to use TEL effectively. Interventions that transform faculty require bold decisions to foster creativity and enable learning content and curriculum transformation as "educators' roles are changing from managing content to connecting learners in new ways to other learners, resources, and expertise" (Schwier, 2010, p. 91).

Changes in technology may introduce uncertainty and lead to technophobia (Christensen \& Knezek, 2008, p. 352). For example, during this study, the versions of computer operating system, interactive whiteboard software, Microsoft Office $^{\mathrm{TM}}$ programs, and logon authentication used by the university changed. Professional development has to focus on holistic coping strategies to build technological confidence, rather than on an overload of detailed information and mechanistic operating procedures (Minovic, Stavljanin, Milovanovic, \& Starcevic, 2008). However, faculty hold the key to the successful integration of learning technologies. The SCTE faculty is committed to the integration of learning technologies. Faculty's perceptions show a strong concern for SCTE students, many of whom are from disadvantaged backgrounds with low confidence in using technology, inadequate computer literacy, and limited access to the Internet and to technology. TEL has the potential to enhance flexible learning by providing students with permanent access to learning resources and by widening their learning options independent from place and time; and ICT can help to raise quality standards and to create a culture of excellence in teaching and learning by adding digital communication channels for increased collaboration to the course setting.

At many HEIs the innovative potential of TEL is not being systematically utilized for the macro-level of their strategic options and/ or the micro-level of faculty implementation of TEL. The rapid pace of technology development tends to outpace strategic thinking and pedagogical design in higher education. Recent studies show that the diffusion of new technologies threatens TEL integration into universities (Schneckenberg, 2008). Zemsky and Massy (2004) are of the opinion that sustainable integration of ICT into HEIs remains a major challenge and that they should substantially increase efforts to involve and engage faculty, who play a key role in education innovation. Faculty face a growing demand from students to offer a more flexible, technology-enriched course delivery while they themselves increasingly race technology to compete for their 
students' attention. They also face the pedagogical challenges to design innovative learning environments, which respond to the changing needs of technology-able students, and to integrate TEL to further the vision of the HEI (Schneckenberg, et al., 2011).

Faculty require professional development in order to acquire new competences that enable them to know and to judge why, when, and how to use ICT in education. If HEIs want to move forward in an organized way to improve the range and quality of their teaching and learning, they have to define coherent strategic frameworks for e-learning which include the creation of adequate support units and measures which foster the development of ICT-related competences. 


\section{References}

Agyei, D. D., \& Voogt, J . M. (2011). Exploring the potential of the will, skills, tool model in Ghana: Predicting prospective and practicing teachers' use of technology. Computers \& Education, 56(1), 91-100.

Ally, M. (Ed.). (2009). Mobile learning: Transforming the delivery of education and training. Edmonton, AB: AU Press.

Anderson, J ., \& Van Weert, T. (Eds.). (2002). Information and communication technology in education: A curriculum for schools and programme of teacher development. Paris: UNESCO.

Anderson, T., \& Garrison, D. R. (1998). Learning in a networked world: New roles and responsibilties. In C. Gibson (Ed.), Distancelearners in higher education: Institutional responses for quality outcomes (pp. 97-112). Madison, WI: Atwood.

Attwell, G. (2007). The personal learning environments-The future of elearning? eLearning Papers, 2(1). Retrieved from www.elearningeuropa.info/files/media/media11561.pdf

Berring, J . (2004). What is a case study and what is it good for? American Political Science Review, 98(2), 341-354.

Boeije, H. (2002). A purposeful approach to the constant comparative method in the analysis of qualitative interviews. Quality \& Quantity, 36, 391-409.

Burns, R. P., \& Burns, R. (2008). Business research methods and statistics using SPSS. London: SAGE.

Burrell, G., \&Morgan, G. (1979). Sociological paradigms and organisational analysis: Elements of the sociology of corporate life. Aldershot: Ashgate Publishing.

Christensen, R., \& Knezek, G. (2008). Self-report measures and findings for information technology attitudes and competencies. In J . Voogt \& G. Knezek (Eds.), International handbook of information technology in primary and secondary education (pp. 349-365). New York: Springer.

Cohen, L., Manion, L., \&Morrison, K. (2011). Research methods in education (7th ed.). London: Routledge.

Department of Education. (2004). White paper on e-education: Transforming learning and teaching through information communication technologies (ICTs) Retrieved from http:// www.capegateway.gov.za/eng/publications/ white_papers/2004/93586 
Ehlers, U. D., \& Schneckenberg, D. (2008, J une). Webucating the reflective practitioner towards competence development in e-learning. Paper presented at the 3rd International scil Congress 2008, St Gallen, Switzerland.

Elton, L. (1999). New ways of learning in higher education: Managing the change. Tertiary Education and Management, 5, 207- 225.

Errington, P. E. (2001). The influence of teacher beliefs on flexible learning innovation in traditional university settings. Innovation in Open and Distance Learning. Retrieved from http://eprints.jcu.edu.au/11839/

Esterhuizen, H. D., \& Blignaut, A. S. (2011, 2-5 October). A localized socially tranformative learning technology integration framework for ODL. Paper presented at the 24th ICDE World Conference on Open and Distance Learning: Expanding Horizons-New Approaches to Open and Distance Learning (ODL), Nusa Dua, Bali.

Esterhuizen, H. D., Blignaut, A. S., Ellis, S. M., \&Els, C. J . (2012, 26-29 J une). Computer literacy learning emotions of ODL teacher-students. Paper presented at the EdMedia 2012: World Conference on Educational Media \& Technology, Denver, CO.

Hinostroza, J . E., Labbé, C., López, L., \& ost, H. (2008). Traditional and emerging IT applications for learning. In J . Voogt \& G. Knezek (Eds.), International handbook of information technology in primary and secondary education (Vol. 1, pp. 81-93). New York: Springer.

J onassen, D., Davidson, M., Collins, M., Campbell, J ., \& Haag, B. B. (1995). Constructivism and computer-mediated communication in distance education. American J ournal of Distance Education, 9(2), 7-26.

Koehler, M. J ., \& Mishra, P. (2005). Teachers learning technology by design. J ournal of Computing in Teacher Education, 21(3), 94-102.

Koehler, M. J ., \&Mishra, P. (2009). What is technological pedagogical content knowledge? Contemporary Issues in Technology and Teacher Education, 9(1). Retrieved from http:// www.citejournal.org/vol9/iss1/general/article1.cfm

Laurillard, D. (2006). E-learning in higher education. In P. Ashwin (Ed.), Changing higher education: The development of learning and teaching (pp. 71-84). London: Routledge.

Law, N. (2008). Teacher learning beyond knowledge for pedagogical innovations with ICT. In In J . Voogt \& G. Knezek (Eds.), International handbook of information technology in primary and secondary education: Part One (pp. 425-444). New York: Springer. 
Leech, N. L., \& Onwuegbuzie, A. J . (2009). A typology of mixed methods research designs. Qual Quant, 43(2009), 265-275.

Mayes, T. (2001). Learning technology and learning relationships. In J . Stephenson (Ed.), Teaching and learning online: New pedagogies for new technology (pp. 16-26). London: Kogan Page.

McMillan, J . H., \& Schumacher, S. (2001). Research in education: A conceptual introduction ( $5^{\text {th }}$ ed.). New York: Longman.

Minovic, M., Stavljanin, V., Milovanovic, M., \& Starcevic, D. (2008). Usability issues of e-learning systems: Case-study for Moodle learning management system. Paper presented at the On the Move to Meaningful Internet Systems: OTM 2008 Workshops, Monterrey, Mexico.

Mishra, P., \& Koehler, M. J . (2006). Technological pedagogical content knowledge: A framework for teacher knowledge. Teachers College Record, 108(6), 1017- 1054.

Moolman, H. B., \& Blignaut, S. (2008). Get set! e-ready, ... e-learn! The e-readiness of warehouse workers. Educational Technology \& Society, 11(1), 168-182.

Riel, M., \& Becker, H. J . (2008). Characteristics of teacher leaders for information and communication technology. In J . Voogt \& D. G. Knezek (Eds.), International handbook of information technology in primary and secondary education (Vol. 1, pp. 397-414). New York: Springer.

Saldãna, J . (2009). The coding manual for qualitative researchers. London: SAGE.

Schneckenberg, D. (2008, 4-5 February). No future learning without present staff-the role of faculty in university innovation. Paper presented at the iLearning Forum 2008, Paris.

Schneckenberg, D., Ehlers, U., \&Adelsberger, H. (2011). Web 2.0 and competenceoriented design of learning - potentials and implications for higher education. British J ournal of Educational Technology, 42(5), 747-762.

Schwier, R. A. (2010). Focusing educational technology research on informal learning environments. Contemporary Educational Technology, 1(1), 90-92.

Simpson, V. (2002). The effect of staff perceptions of online learning when using a non-traditional approach to staff development. Paper presented at the Networked Learning 2002 Conference, University of Lancaster, Sheffield.

Spotts, T. (1999). Discriminating factors in faculty use of instructional technology in higher education. Educational Technology \& Society, 2(4), 92-99. 
Statistica. (2011). (Version 10) [Data analysis software system]. StatSoft Inc. Retrieved from www.statsoft.com.

UNESCO. (2002). Open and distance learning: Trends, policy and strategy considerations Retrieved from http:// unesdoc.unesco.org/images/0012/001284/128463e.pdf

Voogt, J ., \& Knezek, G. (2008). IT in primary and secondary education: Emerging issues. In J . Voogt \& G. Knezek (Eds.), International handbook of information technology in primary and secondary education (pp. xxix-xlii). Washington: Springer.

Wilson, W. (2003). Faculty perceptions and uses of instructional technology. EDUCAUSE Quarterly, 2, 60-62.

Zemsky, R., \& Massy, W. F. (2004). Thwarted innovation-what happened to elearning and why (A Learning Alliance report). The Learning Alliance for Higher Education.

\section{Athabasca University $\mathbf{A}$}

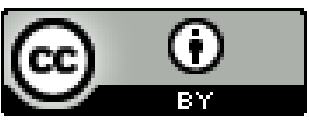

